\title{
Three-Dimensional Culture Systems in Gastric Cancer Research
}

\author{
George Alzeeb ${ }^{1}{ }^{\circledR}$, Jean-Philippe Metges ${ }^{2}$, Laurent $\operatorname{Corcos}^{1,2}(\mathbb{D}$ and \\ Catherine Le Jossic-Corcos $1, *$ iD \\ 1 Inserm, University Brest, EFS, UMR 1078, GGB, F-29200 Brest, France; george.alzeeb@univ-brest.fr (G.A.); \\ laurent.corcos@univ-brest.fr (L.C.) \\ 2 CHU de Brest, Inserm, University Brest, EFS, UMR 1078, GGB, F-29200 Brest, France; \\ jean-philippe.metges@univ-brest.fr \\ * Correspondence: catherine.corcos@univ-brest.fr
}

Received: 21 August 2020; Accepted: 27 September 2020; Published: 29 September 2020

Simple Summary: It is getting more and more clear that cancer cell culture models are switching from two-dimension to three-dimensional, in order to better reflect in vivo situations where tumor cells have to cope with a highly interactive three-dimensional microenvironment. Several such culture models have been reported, predominantly multicellular tumor spheroids (MCTS) and patient-derived tumor organoids (PDTO). These are used both to investigate fundamental aspects of cancer development and as test systems for innovative therapies against gastric cancer, the fifth most common cancer and the third leading cause of cancer-related deaths worldwide. The authors review the actual state of research in this field to provide an overview of the contribution of MCTS and PDTO, especially in the areas of molecular profiling, drug discovery, pathogen infection, and personalized medicine.

\begin{abstract}
Gastric cancer (GC), which includes cancer of the esophagus, the oesophagogastric junction, and the stomach fundus, is highly deadly with strong regional influence, Asia being the most affected. GC is often detected at late stages, with 30\% of metastatic cases at diagnosis. Many authors have devised models to both unravel the mechanisms of GC development and to evaluate candidate therapeutics. Among these models, 2D-cell cultures are progressively replaced by 3D-cell cultures that recapitulate, much more comprehensively, tumor cellular and genetic heterogeneity, as well as responsiveness to environmental changes, such as exposure to drugs or irradiation. With respect to the specifics of GC, there are high hopes from such model systems, especially with the aim of identifying prognostic markers and novel drug targets.
\end{abstract}

Keywords: gastric cancer; spheroids; organoids; personalized medicine

\section{Introduction}

Gastric cancer (GC) is the fifth most common cancer and the third leading cause of cancer-related deaths worldwide, according to data from Global Cancer Statistics 2018 [1]. Adenocarcinomas of the esophagogastric junction (AEG) overlap histologically with GC and constitute an entity with rising incidence rates [2,3]. Lauren's criteria are the most widely used to classify gastric adenocarcinomas, differentiating them histologically into intestinal and diffuse types [4]. Environmental factors such as Helicobacter pylori (H. pylori) infections, the greatest risk factor for GC [5], diet, and lifestyle are often associated with the intestinal type, while the diffuse type is more often associated with genetic abnormalities [6]. The Cancer Genome Atlas (TCGA) research network separated gastric adenocarcinomas into four different molecular subgroups: (i) positive for the Epstein-Barr virus (EBV) with frequent PIK3CA mutations and CDKN2A silencing, (ii) a microsatellite instable (MSI) 
subtype with a hyper-mutation phenotype, (iii) a genomically stable (GS) subtype displaying diffuse histology and frequent CDH1 and RHOA mutations, and iv) a chromosomal instable (CIN) subtype displaying aneuploidy and frequent mutations of TP53 as well as activation of the receptor tyrosine kinase (RTK)-RAS pathway [7]. The molecular characterization of AEG revealed their high similarity to the CIN subtype of GC [8]. The prognosis of GC is poor and most advanced forms of the disease still remain incurable [9]. Hence, GC treatment remains a major challenge and relies on surgical resection as the primary curative modality, i.e., for localized forms. Nonetheless, complementary approaches, such as neo-adjuvant and adjuvant chemotherapy (5-fluoruracil, oxaliplatin, docetaxel and epirubicin), have shown improved survival rates [10-12]. In addition, genetic alterations represent molecular targets for novel treatment options. So far, the only approved targeted therapies are: (i) anti-human epidermal growth factor receptor-2 monoclonal antibody "trastuzumab" and (ii) anti-vascular endothelial growth factor receptor-2 monoclonal antibody "ramucirumab" [13,14], while other therapeutic targets like Programmed cell Death protein 1 (PD-1) inhibition are under clinical investigation [15]. Although treatment effectiveness has improved during the past decade, GC survival rates remain poor [16]. This calls for an urgent need to develop innovative therapies available to GC patients.

The conventional in vitro cancer model used to screen novel therapies is the monolayer two-dimension (2D) cancer cell line (CCL) culture [17]. 2D culture models impose unnatural geometric and mechanical constraints by adhering cells to an artificial substrate (plastic or glass). Such a culture affects cell polarity and therefore, potentially, tumor phenotypes. Three-dimensional (3D) culture systems have been developed to better mimic the functional aspects of tissues [18]. This results from (i) the organization of cells in layers with different proliferation rates, (ii) the formation of diffusion gradients of nutrients, oxygen and metabolic wastes, (iii) the specifics of cell-cell interactions, (iv) the expression of specific genes and (v) induction of chemoresistance [19-21]. Several 3D culture models have been reported [22], predominantly multicellular tumor spheroids (MCTS) [23] and patient-derived tumor organoids (PDTO) [24,25]. The main characteristics of these 3D models are presented in Table 1.

Table 1. Comparison between spheroids and organoids. (++ favorable, + possible), See references [26-30] for examples of studies that used either spheroids or organoids methodologies.

\begin{tabular}{ccc}
\hline 3D Culture Models & Spheroids & Organoids \\
\hline Origin & Cancer cell lines & Patient tumor \\
Protocol & Easy to use & Delicate \\
Architecture & Simplified & Closer to organ \\
Reproducibility & High & Medium-high \\
Cellularity & Defined cell type & Different cell types \\
Cancer subtype modeling & + & ++ \\
Biological material produced & Abundant & Abundant \\
Genetic manipulation & ++ & ++ \\
Co-culture & ++ & + \\
High-throughput drug screening & ++ & + \\
Prediction of clinical drug response in vitro & + & ++ \\
Cost & Low & Medium \\
Biobanks & Unavailable & Available \\
\hline
\end{tabular}

MCTS models promote the formation of well-developed spheroids that resemble avascular tumor sites or micrometastatic regions in vivo [31]. Different co-culture approaches have been developed, including mixed populations of tumor cells and cancer associated fibroblasts (CAF), which showed increased ability to form spheroids [32]. Several studies validated the anticancer therapeutic potential of targeting the interactions between CAF and carcinoma cells [33]. However, using CCL to produce MCTS renders this approach hardly patient specific because most tumors contain highly heterogeneous subsets of cancer cells [34]. In vivo animal testing research is often employed for observing the effects on a living subject. The gold standard in vivo model for tumor development and analysis is patient-derived xenograft (PDX) [35]. Such a model conserves the clinical tumor architecture, the genotypic and 
phenotypic characteristics of the primary tumor as well as interactions with the microenvironment and the characteristics of patient's tumor, recapitulating the inter-tumor heterogeneity [36]. However this still does not provide immediate clinically actionable data [37]. In addition, their use is quite expensive and time consuming, and raises ethical issues, at times where alternative in vitro/ex vivo models are gaining momentum. These reasons make in vivo models unsuitable for routine testing purposes and encourage the application of 3D cultures that permit recapitulating several mechanisms of drug resistance found in tumors in vivo.

Huge efforts in preclinical personalized therapy testing were explored by the recent development of PDTO as ex vivo models of human cancers, including GC [38]. Organoids are 3D cultures of multiple organ-specific cells of different types that can retain the morphologies and gene expression profiles of their organs of origin [39]. Organoids enable drug screening for personalized therapies as they provide genotypic stability and constitute a valuable tool to study pathogen infections [40,41]. A comparison of the main specificities of 2D, 3D, and PDX animal models is presented in Table 2.

Table 2. Comparison between 2D, 3D cell culture and PDX animal models [42-45].

\begin{tabular}{|c|c|c|c|}
\hline $\begin{array}{l}\text { Test System Main } \\
\text { Features }\end{array}$ & 2D Cell Culture $[42,43]$ & 3D Cell Culture [44] & PDX Animal Model [45] \\
\hline Physiological relevance & Limited & $\begin{array}{c}\text { Better than 2D standard } \\
\text { culture }\end{array}$ & $\begin{array}{l}\text { Most physiological } \\
\text { environment }\end{array}$ \\
\hline Model complexity & Limited & Complex & Very complex \\
\hline Gene expression & Stable at early passages & Close to in vivo tumors & Close to in vivo tumors \\
\hline Immune system & $\begin{array}{l}\text { No but co-cultures of } \\
\text { cancer cells and immune } \\
\text { cells possible }\end{array}$ & $\begin{array}{l}\text { No but co-cultures of } \\
\text { cancer cells and immune } \\
\text { cells possible }\end{array}$ & No \\
\hline Efficient drug screening & Yes & Yes & No \\
\hline Disease modeling & Naive & Feasible & Sophisticated methods \\
\hline Data provider & Easily exploitable & Easily exploitable & Hardly exploitable \\
\hline $\begin{array}{c}\text { Controlled } \\
\text { microenvironment }\end{array}$ & Yes & Yes & No \\
\hline Reproducibility & Favorable & Not so favorable & Unsuited \\
\hline Cost & Low & $\begin{array}{c}\text { Some expensive } \\
\text { materials and special } \\
\text { equipment required }\end{array}$ & High \\
\hline $\begin{array}{c}\text { Ethical and regulatory } \\
\text { issues }\end{array}$ & No & No & No \\
\hline
\end{tabular}

In this review, we present the current status of in vitro / ex vivo 3D models of human GC as a surrogate to in vivo tumors. We describe established MCTS and PDTO methods in GC models and present an overview of important findings from different spheroids- and organoids-based studies, especially in the fields of molecular profiling, drug discovery, pathogen infection and personalized medicine. Lastly, we also attempt to propose ways for improving the relevance of next-generation 3D models.

\section{Three D Multicellular Tumor Spheroid Model}

Since Sutherland et al. established MCTS in the 1970s [46], this model has been one of the most commonly explored and characterized among the currently available 3D in vitro tumor models [47]. MCTS are aggregates of CCL grown with or without scaffolds representing avascular tumor nodules or micro-metastases [48]. Spheroids with diameters larger than 400-500 $\mu \mathrm{m}$ sustain oxygen and nutrient gradients associated with specific functional domains (proliferative outer layer, quiescent intermediate 
layer, and the necrotic center) [49] (Figure 1). As a result, protein and gene expression profiles of MCTS are closer to those of tumors than 2D tumor cell cultures [50]. In addition, MCTS can be constructed from tumor cells alone or combined to other cell types that can produce an extracellular matrix (ECM). They can be used to analyze the influence of 3D-specific cell-cell interactions on tumor progression, cell invasion or angiogenesis. As such, they are well suited to recapitulate the complexity and the cellular heterogeneity of tumors, a hallmark of cancer that may explain resistance to chemotherapy and participate in metastatic invasion. Hence, different 3D-co-culture approaches have been developed to analyze the interaction of tumor cells, fibroblasts, stem cells, adipocytes, or other cells present in the tumor microenvironment and to study the influence of these interactions on tumor progression or cell invasion [51-53].

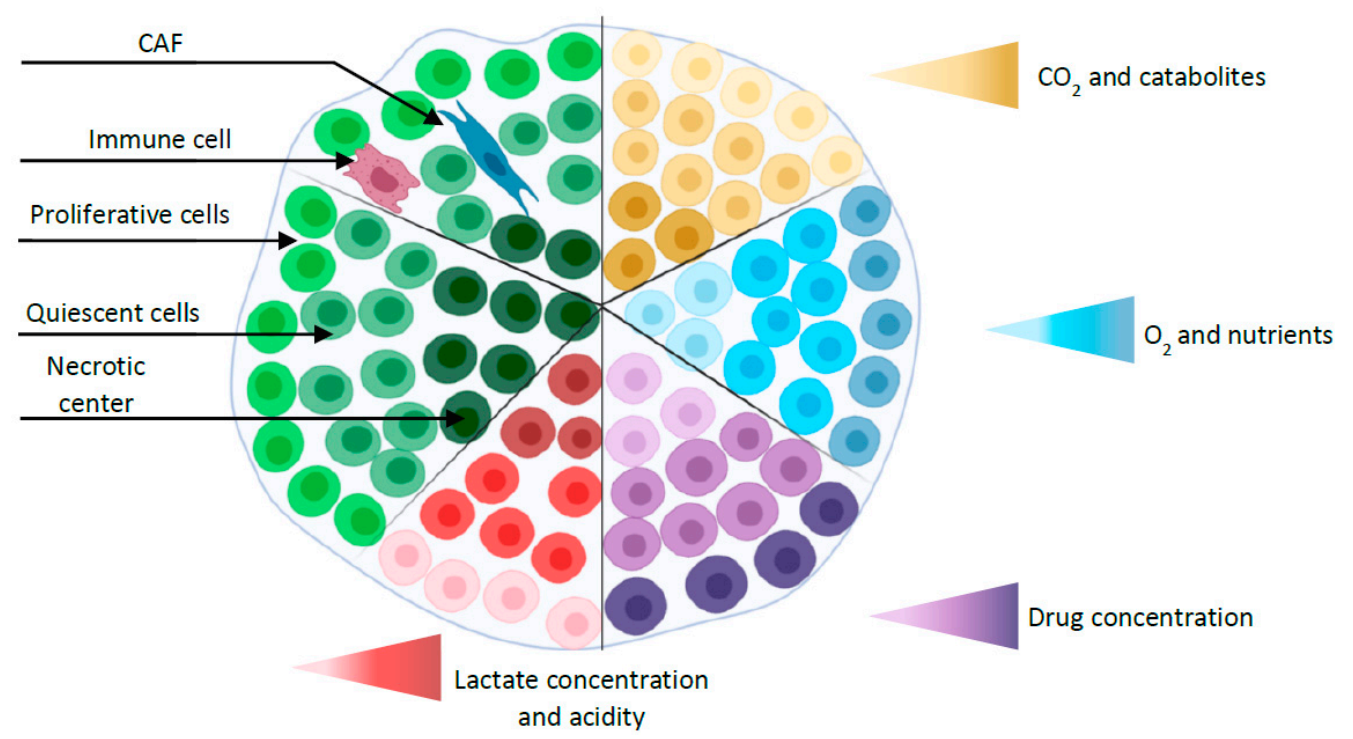

Figure 1. Simplified representation of a spheroid with different layers (proliferative outer layer, a quiescent intermediate layer, and the necrotic center) and gradients (oxygen, nutrients, $\mathrm{CO}_{2}$, catabolites, and drug concentration). Co-culture spheroid is represented by the addition of cancer-associated fibroblast (CAF) and immune cell.

\subsection{MCTS Production Methodologies}

Spheroid formation methodologies can be divided into two major categories: (i) scaffold-based models that take advantage of diverse natural (collagen, fibronectin, agarose, laminin, gelatin) [54], or synthetic (polyethylene oxide or polyethylene glycol) [55] materials to mimic in vivo tumor-ECM interactions [56] and (ii) scaffold-free models, which include mainly non-adherent, suspension, and hanging drop cultures, result in preventing cells attachment to the support, thereby forcing them to aggregate and form spheroids [49]. The plates used for this method are made non-adherent by coating them with an inert, non-cytotoxic and non-degradable substrate: agarose or poly-2-hydroxyethyl methacrylate (poly-HEMA) [57]. The principle of suspension culture methods is to keep the cells in suspension, either by agitation or by increasing medium viscosity (by addition of carboxy-methyl-cellulose) [58], but the spheroid size cannot be controlled, which can pose a problem when used in drug testing [59]. Finally, the hanging drop method involves cell suspension drops deposited on the underside of an adherent tissue culture lid. Cells aggregate at the bottom of the drop by gravity and form spheroids of uniform sizes [60]. However, the drops cannot exceed a volume of $50 \mu \mathrm{L}$ in order to resist gravity [61]. The non-adherent surface method has been widely used for GC studies [62] (Table 3). 
Table 3. Description, advantages and disadvantages of commonly used MCTS culture techniques. (* Refers to studies on colorectal cancer).

\begin{tabular}{|c|c|c|c|c|}
\hline $\begin{array}{l}\text { Spheroids Production } \\
\text { Methods }\end{array}$ & Description & Advantages & Disadvantages & References \\
\hline Scaffold-based models & $\begin{array}{l}\text { 3D construction that provides } \\
\text { an ECM capable of } \\
\text { supporting cells }\end{array}$ & $\begin{array}{c}\text { Simple } \\
\text { Mimic in vivo microenvironment } \\
\text { Cell-ECM interactions } \\
\text { Long-term culture } \\
\text { Directly visualize and analyze }\end{array}$ & $\begin{array}{c}\text { Difficulty of cell recovery } \\
\text { Scaffold consistency can be variable across lots } \\
\text { Nonuniform control (composition, size) } \\
\text { Co-culture delicate } \\
\text { Not suitable for drug testing }\end{array}$ & {$[27,63]$} \\
\hline Non-adherent surfaces & $\begin{array}{l}\text { Prevent attachment } \\
\text { to the support }\end{array}$ & $\begin{array}{c}\text { Simple } \\
\text { Available pre-coated plates } \\
\text { Uniform spheroid size control } \\
\text { Ease of cell recovery } \\
\text { Long-term culture } \\
\text { Co-culture feasible } \\
\text { Useful for drug screening } \\
\text { Directly visualize and analyze }\end{array}$ & $\begin{array}{l}\text { Low throughput production } \\
\text { Defined co-culture cellular ratio } \\
\text { Requires transfer of spheroids for analysis }\end{array}$ & [64-67] \\
\hline Suspension culture & $\begin{array}{l}\text { Keeps the cells in suspension } \\
\text { to avoid sedimentation }\end{array}$ & $\begin{array}{l}\text { High throughput production } \\
\text { Homogeneous media composition } \\
\text { Long-term culture }\end{array}$ & $\begin{array}{c}\text { High shear force } \\
\text { Nonuniform control (composition, size) } \\
\text { Not easily suitable for drug testing } \\
\text { Requires special equipment } \\
\text { Requires a centrifugation step }\end{array}$ & {$[23]$ * } \\
\hline Hanging drop technique & $\begin{array}{l}\text { Gravity based spheroid } \\
\text { formation }\end{array}$ & $\begin{array}{l}\text { Simple } \\
\text { Uniform spheroid size control } \\
\text { Co-culture feasible }\end{array}$ & $\begin{array}{c}\text { Small size of spheroids } \\
\text { Low throughput production } \\
\text { Tedious spheroid handling and transfer } \\
\text { Difficulty of long-term culture } \\
\text { Defined co-culture cellular ratio } \\
\text { Not suitable for drug testing }\end{array}$ & {$[68-70]$ * } \\
\hline
\end{tabular}




\subsection{Applications of MCTS in Gastric Cancer}

\subsubsection{Gene Expression Profiling}

Genetic and epigenetic alterations contribute to the development and progression of multifactorial diseases such as GC [71]. Investigating the gene expression profiles of GC paves the way towards identifying novel diagnostic or prognostic biomarkers and developing future individualized medicine strategies. In vitro 3D experiments have gone a long way in understanding the molecular aspects of complex diseases [72]. CD44, a cell surface adhesion marker expressed by cancer stem cells (CSC) [73] has been reported as overexpressed in GC spheroids [64]. Oue et al. showed that KIFC1 and KIF11, two members of the kinesin-14 family, were overexpressed in spheroids compared to parental cells [74,75], while their knockdown inhibited spheroid formation [74,76]. In a similar context, this group also reported the under-expression of the claspin (CLSPN) gene, which codes for a nuclear protein involved in DNA replication and S-phase regulation, in spheroids [77]. Recently, Lee et al. demonstrated, using a limiting dilution protocol in a microwell-based culture chip, that gene expression of spheroid-forming cells was closely related to histological diffuse and intestinal type [78]. They observed an increase in expression levels of SOX2, a transcription factor expressed in stem cells), CD44 and E-cadherin in the diffuse type spheroid cell lines (SNU-638 and SNU-484) [79]. In addition, the expression of ERBB3 increased in spheroids made from intestinal type cell lines (MKN-28 and NCI-N87) [79]. miRNA expression was also investigated in GC MCTS models. Magalhães et al observed that the expression of has-miR-29c-5p, which regulated the expression of DNMT3A, CDC42, RCC2, and CDK6, was lower in the 3D model compared to 2D [26]. Changes in the microenvironment of the in vitro cells by $3 \mathrm{D}$ cultures can also impact on gene expression by modifying alternative splicing [80]. Indeed, a study by Branco da Cunha et al. showed an alternative splicing product of CD44 in GC spheroids, where the standard CD44 isoform (CD44s) was substituted by CD44 variant 6 (CD44v6) [81]. This increased progressively with the advancement of GC stages, from gastric pre-neoplastic lesions to advanced carcinoma [82]. Consequently, targeting the genes that distinguish MCTS from monolayer cell cultures introduces promising anticancer therapies. However, current studies on gene expression profiles of GC spheroids only scratch the surface and further studies need to be conducted to further clarify this process.

\subsubsection{Gastric Cancer Stem Cells: Biomarkers Identification}

Cancer stem cells (CSC) are defined as a subpopulation of cancer cells that have a high capacity of self-renewal and differentiation into mature tumor cells, where multiple pathways are involved such as Notch, Wnt, Hedgehog and PI3K [83,84]. CSC constitute less than $5 \%$ of total tumor cells but they may play a crucial role as initiators of the heterogeneous lineage of cancer cells that constitute the tumor $[85,86]$. Because of their intrinsic resistance to anticancer drugs, CSC remains after chemotherapy or radiation therapy could be responsible for relapse after treatment. In addition, a poor prognosis of GC was associated with the expression of stem cell markers and related proteins, including CD44, SOX2 and OCT4/3 [87]. Nonetheless, gCSC markers have not been unambiguously identified [87]. For example, Rocco et al. reported that $\mathrm{CD} 44^{+} / \mathrm{CD} 133^{+}$cells, detectable in primary GC, did not exhibit stem-like properties [88]. In this section, we will focus on studies that apply MCTS models to provide additional and better evidence of specific cell markers to identify gCSC.

Takaishi et al. identified gCSC for the first time, using CD44 as a marker from a panel of human gastric CCLs. CD44 ${ }^{+}$cells could self-renew and form MCTS in a serum-free medium. CD44 knockdown reduced spheroid colony formation [89]. Han et al. reported that $\mathrm{CD} 44^{+} / \mathrm{EpCAM}^{+}$(Epithelial Cell Adhesion Molecule) cells grew exponentially in vitro as cancer spheres and had greater resistance to anticancer drugs than other subpopulations of cells. These results suggested that CD44 $/ \mathrm{EpCAM}^{+}$ cells could be used as a model system for gCSC research [90], although these markers are not specific of gCSC. It resulted that spheroid body formation has been increasingly used as a functional approach for enriching in stem cell markers. Liu et al. were the first to develop spheroid body cells from 
human gastric CCL 'MKN-45'. They demonstrated that these cells could generate greater numbers of new spheroid bodies than the parental cells and that spheroid body-forming cells were capable of self-renewal and proliferation, which are important CSC characteristics [91]. In addition, when cultured in stem cell conditioned media, these spheroid body-forming cells showed a significant overexpression of CD44 and ABCG2 (adenosine triphosphate binding cassette transporter G2) compared to the parental cells [92]. Furthermore, Zhang et al. found that spheroid cells from gastric CCL could self-renew and may also play roles in tumor initiation, chemo-resistance, and migration [87]. As already mentioned [79], using a limiting dilution protocol and a microwell-based culture chip to produce spheroids, Lee et al. demonstrated that these spheroids had larger populations of cells with stem cell-like properties, compared to spheroids formed by conventional tumor spheroid culture methods [78]. It is worth noting that these methods are hindered by poor single-cell seeding and low throughput. Other molecules have been reported as CSC-associated markers in GC. While Jiang et al. suggested that CD90 could be used to identify and isolate gCSC [93], Tian et al. documented a high expression of SOX2 in gastric MCTS and demonstrated the important role of SOX2 in sustaining stem cell properties [94]. In addition, using the MCTS method to isolate gCSC, Ptch and Gli1 (Sonic hedgehog (SHH) pathway target genes) were shown to be more expressed in MCTS cells than in adherent cells, suggesting that the $\mathrm{SHH}$ pathway was essential for the maintenance of CSC in human GC [95]. Ohkuma et al. demonstrated, using $3 \mathrm{D}$ invasion assays, that gastric $\mathrm{CD} 71^{-}$cell subpopulations had higher migratory and a more invasive potential compared to $\mathrm{CD} 71^{+}$cells, suggesting that low expression of CD71 could mark subpopulations of gCSC [96]. In addition, Yoon et al. found increased activity of RhoA in diffuse gCSC and a decreased spheroid formation after RhoA inhibition [97]. Despite this evidence, more studies are needed to further identify and characterize common gCSC biomarkers, especially as a means to better discriminate between CSC subpopulations, which will help to introduce better GC therapies $[28,98]$.

\subsubsection{Drug Discovery}

Standard 2D cell cultures have largely contributed to the development of many cancer therapies. However, the limitations of this model in reproducing in vivo tumor complexity and pathophysiology [99] may be one cause of the high attrition rate for cancer drugs entering early clinical trials [100]. Admittedly, culturing cells in 3D differentially impacts on their sensitivity to cytotoxic agents, as compared to 2D cultures, and usually makes them more resistant to treatment [101]. In this section, we will provide an overview of the implications of MCTS models in the development of anticancer drugs as well as in the discovery of novel treatment targets in GC.

As discussed earlier in this review, gCSC are involved in tumor maintenance, resistance to treatments and tumor progression. Novel treatment modalities targeting gCSC have been developed using 3D models. Courtois et al. analyzed MCTS spheroid formation revealing CSC-presence and showed that metformin, an anti-diabetic drug with anti-proliferative effects, targeted gCSC, indicating that use of metformin could be a promising strategy to inhibit tumor growth [102]. Akrami et al. showed that ibuprofen, a nonsteroidal anti-inflammatory drug, prevented the initiation and the progression of GC [103]. They suggested that the anticancer effect of ibuprofen on gCSC was linked to inhibition of the Wnt/ $\beta$-catenin signaling pathway [104]. After demonstrating its importance in sustaining CSC properties, Tian et al. proposed SOX2 as a potential target for GC therapy [94]. Similarly, Nishikawa et al. suggested that ALDH in gCSC may turn into a novel treatment target [105]. In addition, Koh et al. found that pantoprazole downregulated JAK2/STAT3 signaling, while inhibiting cellular migration or invasion in GC at the same time [106]. Because the efficacy of anticancer drugs relies on their ability to penetrate tumors efficiently, MCTS models are an ideal platform in view of their capacity to generate an ECM that obstructs drug penetration [107]. From that perspective, Sha et al. have constructed a recombinant protein named anti-EGFR-iRGD consisting of an anti-EGFR VHH (the variable domain from the heavy chain of the antibody to epidermal growth factor receptors) fused to iRGD, a tumor-specific binding peptide with high permeability. Anticancer activity and penetration of anti-EGFR-iRGD were evaluated with the MCTS model. Results from this study showed 
improvements in MCTS penetration as well as anti-GC efficacy when the anti-EGFR was fused with iRGD [27]. In addition, anti-EGFR-iRGD could enhance the efficacy of chemotherapeutic drugs, such as doxorubicin, bevacizumab, and placitaxel, in the inhibition of GC [27,108]. Furthermore, sTRAIL-iRGD, a recombinant protein with a high permeability index, displayed an anti-tumor effect in MCTS, with limited systemic toxicity $[63,109]$. Immunotherapy has had its fair share of applications using MCTS. Examples include exploring tumor immune escape mechanisms and screening immunotherapy agents or combinations pre-clinically. MCTS were also used for the evaluation of penetration and cytotoxicity of immune cells [110]. Zhou et al. established MCTS from a human gastric CCL to evaluate the cytotoxicity resulting from PD-1 blockade [111], a strategy to improve cancer therapy in the immuno-oncology field [112]. MCTS were formed in a medium containing IFN- $\gamma$ and TNF- $\alpha$ to obtain PD-L1-expressing spheroids. The spheroids were then incubated with T cells in the absence or presence of PD-1 blockade. PD-1 blockade enhanced T-cell cytotoxicity against gastric spheroids expressing PD-L1 [111]. The potential of 3D culture models for the development of new anticancer strategies has evolved lately [113], demonstrating that CSC are more resistant to drugs than other malignant cells in the tumor aggregate [114]. Nonetheless, the heterogeneity of MCTS models could lead to reproducibility problems, leading to disputable biological information not well suited to test and select appropriate potential anticancer drugs [115].

\section{Gastric Organoids}

Although generic approaches, such as MCTS models, have participated in improving GC treatment, patient survival rates remain poor and there is still an urgent need to develop novel effective therapies with a model that would allow taking into account the genetic make-up of the individual tumor and provide immediate treatment selection. So-called organoids are one relevant option, although there is still no consensus on the definition of 'organoid' [39]. In general, organoids are in vitro 3D culture models grown from stem cells of primary tissues [116]. They can recapitulate key features and functions of their organs of origins such as architecture and gene expression profiles [117]. The many potential applications of this novel technology are beginning to be explored and used in many research areas, particularly in cancer research. The organoids co-culture approach can mimic the tumor immune microenvironment preserving $\mathrm{T}$ cell receptor and immune check point [118]. The first PDTO was established in 2011 when Sato et al. developed a long-term in vitro culture protocol for primary human epithelial cells isolated from small intestinal adenomas, metaplastic Barret epithelium and colon cancer tissues [119]. This innovation goes back to the identification of a particular intestinal stem cell marker, the leucine-rich repeat-containing G protein-coupled receptor 5 (Lgr5) by Barker et al. in 2007 [120]. Sato et al. next reported the first protocol that allowed establishing adult stem cells-derived organoids using Lgr5 ${ }^{+}$stem cells from intestinal crypts [121]. Since then, this protocol was applied to develop organoids from different organs including the pancreas [122], liver [123], esophagus [124], prostate [125], lung [126], breast [127], brain [116], and others [128]. Gastric organoids development was based on the localization of highly proliferative Lgr5 ${ }^{+}$gastric stem cells at the base of pyloric glands [129], shortly after the identification of Lgr5 as an intestinal stem cell marker [120]. This identification was facilitated by the fact that the gastric epithelium, like the intestinal epithelium, is constantly renewed and filled with rapidly proliferating stem cells. Stange et al. found, at the gland base of the gastric corpus, specialized chief cells marked by 'Troy'. They demonstrated that a single Troy ${ }^{+}$ chief cell could generate gastric organoids [130]. In the following, we describe briefly the culture of patient-derived gastric cancer organoids (PDTO) and review important findings from organoids applications in GC studies.

Gastric organoids can be established from normal and cancerous gastric tissues. They are embedded into an ECM (matrigel) in a manner that recapitulates 3D in vivo conditions [129,131]. Methods used for culturing organoids from normal tissues have been adapted to successfully produce organoids from several human cancers [132]. PDTO can be propagated from surgical tumor specimens or endoscopic biopsies [133] (Figure 2). In general, protocols used to culture gastric organoids start from rinsing 
and mincing tumor tissues into small pieces $\left(2-5 \mathrm{~mm}^{3}\right)$. Released tumor cells from bulk tissues are then resuspended in matrigel [134] and overlaid with culture medium supplemented with essential components such as epidermal growth factor (EGF), noggin, R-spondin1, Wnt, fibroblast growth factor (FGF), gastrin, transforming growth factor (TGF), nicotinamide, insulin-like growth factor (IGF), and p38 inhibitor glycogen synthase kinase (GSK) [135]. These supplements make organoids culture environments very complex and different from conventional 2D culture media, which may limit strict comparisons in cell behavior. Gastric organoids tend to have a conserved architecture, with gastric glands budding around a central lumen [39]. However, contamination by epithelial and stromal cells, as well as the scarcity of cancer cells, represent a major challenge in culturing PDTO $[130,136]$. Primary PDTO appear like a mosaic of normal and cancer cells. Mechanical or enzymatic disruption allows passing organoids to maintain the culture for many months and even be cryo-preserved. In addition, PDTO biobanks were created either from primary [131,137] or metastatic tumors [138]. These biobanks offer a biological access to human GC, facilitate drug screening, validate biomarkers, and enable personalized medicine. However, statistical issues are raised, since too small a repertoire of banked cells might not be representative enough of the genetic heterogeneity of GC.

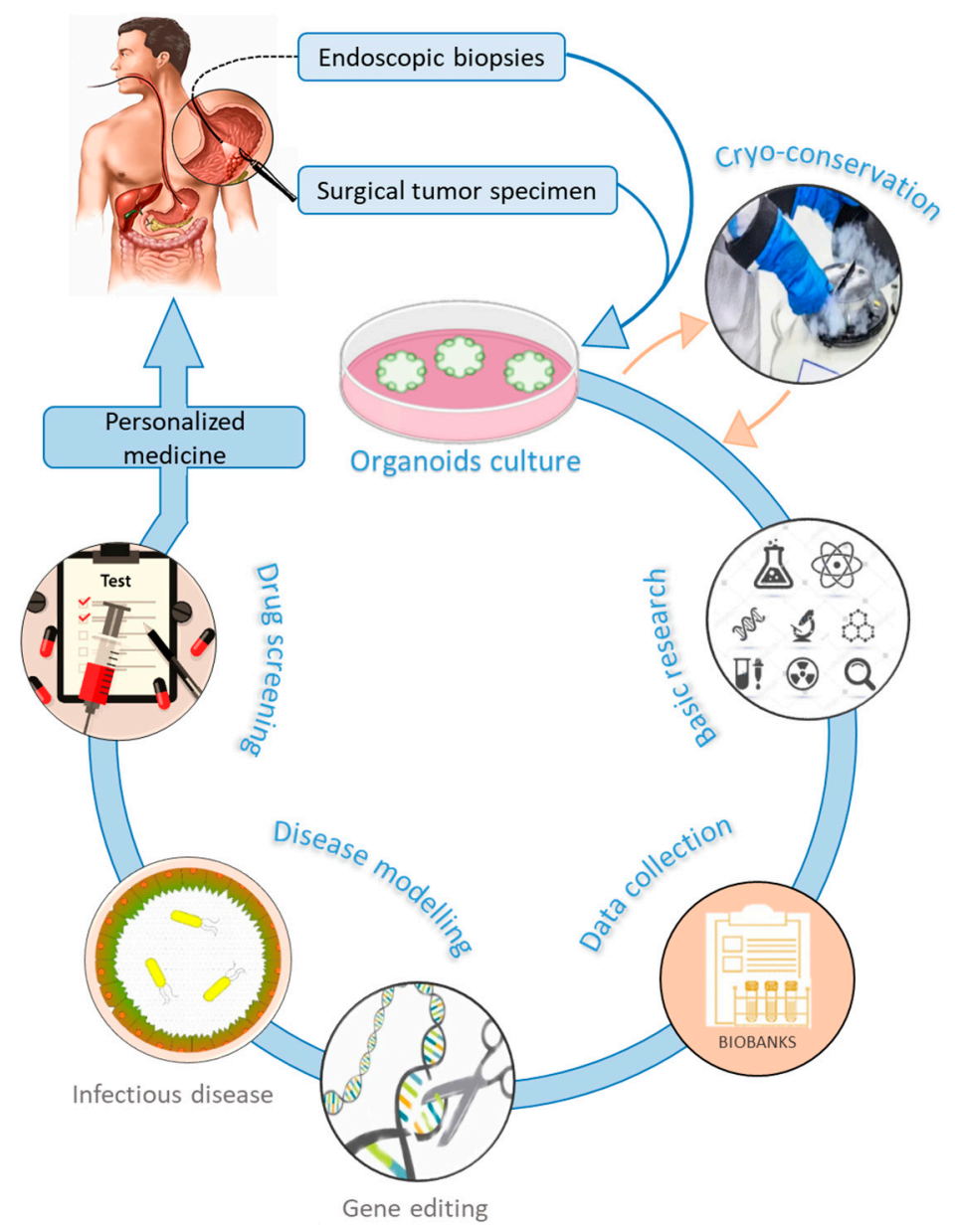

Figure 2. Graphical representation of gastric organoids applications and implication in personalized medicine.

\subsection{Applications of Organoids in Gastric Cancer}

\subsubsection{Helicobacter Pylori Infection}

H. pylori is a highly harmful human pathogen that infects approximately $60 \%$ of the world's population [139]. H. pylori infection causes chronic gastritis, the major risk factor for GC 
development $[140,141]$. Injection of the cytotoxicity-associated gene A (CagA) by H. pylori into gastric epithelial cells induces pathogenesis [142]. Additionally, CagA upregulates Sonic Hedgehog (Shh), the regulator of gastric epithelial differentiation and function $[143,144]$. The majority of data generated on $H$. pylori pathogenesis was obtained from gastric CCL or in vivo animal models. However, the mechanisms of $H$. pylori infection that trigger GC initiation are poorly described. Bartfeld et al. developed a system to culture human gastric organoids from adult stem cells (aSCs) that can be productively infected by H. pylori [135]. Similarly, McCracken et al. reported the de novo generation of human gastric organoids through the direct differentiation of human pluripotent stem cells (hPSCs), to be used to model the pathophysiological response of the gastric epithelium to H. pylori [30]. Two hallmarks of $H$. pylori infection, the enhancement of gastric epithelial cells proliferation and the activation of nuclear factor- $\mathrm{KB}$ signaling, were discovered in 2D cell culture and were then validated in H. pylori-infected gastric organoids $[135,145]$. In addition, Wroblewski et al. showed that $\beta$-catenin was involved in the proliferation mechanism in H. pylori-infected organoids [146]. The activation of $\beta$-catenin and snail altered the expression and the localization of claudin-7, a protein implicated in the formation of tight junctions between epithelial cells [146]. In addition, Bertaux-Skeirik et al. have explored a new role of CD44 in H. pylori-induced proliferation, based on the fact that CD44 acts as a co-receptor for c-Met [147]. H. pylori-induced gastric pathology was contributed by the pathogen's ability to colonize, alter and manipulate $\mathrm{Lgr}^{+}$progenitor-stem cells [148]. Moreover, Holokai et al. developed a human gastric organoid-immune cell co-culture system that allowed studying PD-L1 and PD-1 interactions, located on the gastric epithelial cells and the host's immune cells, respectively, during H. pylori infection. They suggested that H. pylori infections modulate the PD-L1 immune checkpoint which may protect gastric epithelial cells against an immune response [149].

\subsubsection{Gastric Cancer Tumorigenesis}

To date, the links between genotypes and phenotypes in the development of GC are poorly understood. Several transgenic animal models of GC tumorigenesis have been developed [150]. However, these models have all shown limitations linked to genetic background irrelevance, animal resistance and the inability to allow questioning the mechanisms that characterize the aggressive metastatic tumors. Recently however, organoids proved helpful for understanding the functional roles of driver gene mutations in the initiation and progression of cancers including colorectal [151] and gastric cancers. Knocking out CDH1, a tumor suppressor gene, Nanki et al. enhanced the transformation potential of normal gastric organoids to a diffuse GC morphology, indicating the implication of CDH1 in morphological and migratory features of GC. They showed occurrence of divergent genetic and epigenetic routes for developing WNT and R-spondin niche independency. In addition, they suggested that the loss of CDH1 and TP53 induced R-spondin independency uniquely during gastric tumorigenesis [137]. Another study by Sethi et al. showed that knocking out both CDKN2A and TP53 in dysplastic gastric organoids promoted cancer phenotypes [29]. Chen et al. investigated the role of epithelium-stroma interaction in the progression and the maintenance of gastric organoids. They demonstrated that Trp53 $3^{-/}$macrophages present in the early stroma affected wound healing and tumor promotion. Additionally, they identified R-spondin 3 as an endogenous source supplied by fibroblasts that could sustain the growth niche in gastric tissue homeostasis and early cancer development [152]. Wang et al. demonstrated that silencing C8orf76 (chromosome 8 open reading frame 76), a booster of GC cell proliferation, suppressed tumor growth in PDTO [153]. Hence, the organoid model proved highly pertinent to identify several human molecular pathways associated with disease progression.

\subsubsection{Drug Sensitivity and Personalized Medicine}

Intratumor heterogeneity [154] accounts for a large part of the limited benefits of current treatments. PDTO is a powerful ex vivo tool to take into account the genetic heterogeneity of primary tumors [155]. Drug exposure of organoids established from tumors obtained from seven patients treated with 
epirubicin, oxaliplatin, and 5-fluorouracil was correlated with the response of the primary tumor in each patient [156]. In a similar study, Li et al. demonstrated that malignant ascites-derived organoids preserved the histological architecture and the genomic landscape of the corresponding malignant ascite tumor cells, a common manifestation in advanced GC [157]. Vlachogiannis et al. showed the clinical potential of PDTO for selecting the best treatment option in cancers using a compound library of drugs. They also showed their capacity to recapitulate patient responses. Treatment with lapatinib, a tyrosine kinase inhibitor that targets the EGFR and HER2 tyrosine kinases, was effective against ErbB2-amplified PDTO compared to wild-type PDTO [138]. The evolution of translational research, through its applications with PDTO models, makes it emerge as a crucial strategy in personalized medicine programs $[131,158]$. New clinical trials are required to further validate the benefits of GC PDTO in personalized medicine, i.e., assessing the correlation between the in vivo primary tumor response and the ex vivo drug-mediated cytotoxicity. The OPPOSITE trial [159] is aimed at filling this gap.

\section{Concluding Remarks}

In this article, we attempted to provide an overview of the development of the major 3D cell culture models of human GC. This rapidly evolving field, which comprises mainly spheroid and organoid structures, aims at providing an ex-vivo alternative to the quite demanding and expensive PDX in vivo system. Hence, MCTS systems are well suited to analyze the interactions between the cells that compose the tumor, including CSC, CAF, immune and endothelial cells. As such, they are also convenient to analyze the effects of cytotoxic drugs, as well as to identify novel biomarkers. Alternatively, organoids have proven quite useful to address issues such as the contribution of PD-L1/PD1 from immune cells to the susceptibility to infection by helicobacter pylori or the specific roles of genes and gene pathways in gastric tumorigenesis and the response of cancer cells to chemotherapeutic drugs. Hence, these ex-vivo cell culture systems already represent plausible alternatives to PDX or to other animal models. Still, harmonization of techniques is needed to ensure better data reproducibility from the use of 3D models, before these can be seen as the gold standard for the preclinical screening of therapeutic strategies for GC.

Author Contributions: C.L.J.-C. and L.C. selected the subject of the review. J.-P.M. input medical data relative to GC. G.A. prepared the Tables and Figures. All authors analyzed the bibliography and drafted the manuscript. All authors have read and agreed to the published version of the manuscript.

Funding: This work was supported by grants from the INSERM, from Brest University and from the Ligue Contre le Cancer, Comité du Finistère ( ${ }^{\circ}$ RAB18153NNA and n ${ }^{\circ}$ RAB19101NNA to Catherine Le Jossic-Corcos and Laurent Corcos, respectively).

Acknowledgments: George Alzeeb received a fellowship from Brest University ("Contrat Doctoral d'Etablissement"). Laurent Corcos was partially apointed by Brest University Hospital.

Conflicts of Interest: The authors declare no conflict of interest. The sponsors had no role in the design, execution, interpretation, or writing of the study.

\section{References}

1. Bray, F.; Ferlay, J.; Soerjomataram, I.; Siegel, R.L.; Torre, L.A.; Jemal, A. Global cancer statistics 2018: GLOBOCAN estimates of incidence and mortality worldwide for 36 cancers in 185 countries. CA Cancer J. Clin. 2018, 68, 394-424. [CrossRef] [PubMed]

2. McColl, K.E.L.; Going, J.J. Aetiology and classification of adenocarcinoma of the gastrooesophageal junction/cardia. Gut 2010, 59, 282-284. [CrossRef] [PubMed]

3. Arnold, M.; Soerjomataram, I.; Ferlay, J.; Forman, D. Global incidence of oesophageal cancer by histological subtype in 2012. Gut 2015, 64, 381-387. [CrossRef] [PubMed]

4. Lauren, P. The Two Histological Main Types of Gastric Carcinoma: Diffuse and So-Called Intestinal-Type Carcinoma. an Attempt At a Histo-Clinical Classification. Acta Pathol. Microbiol. Scand. 1965, 64, 31-49. [CrossRef] [PubMed] 
5. Venerito, M.; Vasapolli, R.; Rokkas, T.; Malfertheiner, P. Gastric cancer: Epidemiology, prevention, and therapy. Helicobacter 2018, 23, e12518. [CrossRef]

6. Hu, B.; Hajj, N.E.; Sittler, S.; Lammert, N.; Barnes, R.; Meloni-Ehrig, A. Gastric cancer: Classification, histology and application of molecular pathology. J. Gastrointest. Oncol. 2012, 3, 251-261.

7. Bass, A.J.; Thorsson, V.; Shmulevich, I.; Reynolds, S.M.; Miller, M.; Bernard, B.; Hinoue, T.; Laird, P.W.; Curtis, C.; Shen, H.; et al. Comprehensive molecular characterization of gastric adenocarcinoma. Nature 2014, 513, 202-209.

8. Kim, J.; Bowlby, R.; Mungall, A.J.; Robertson, A.G.; Odze, R.D.; Cherniack, A.D.; Shih, J.; Pedamallu, C.S.; Cibulskis, C.; Dunford, A.; et al. Integrated genomic characterization of oesophageal carcinoma. Nature 2017, 541, 169-174.

9. Hohenberger, P.; Gretschel, S. Gastric cancer. Lancet 2003, 362, 305-315. [CrossRef]

10. Cunningham, D.; Allum, W.H.; Stenning, S.P.; Thompson, J.N.; Van De Velde, C.J.H.; Nicolson, M.; Scarffe, J.H.; Lofts, F.J.; Falk, S.J.; Iveson, T.J.; et al. Perioperative chemotherapy versus surgery alone for resectable gastroesophageal cancer. N. Engl. J. Med. 2006, 355, 11-20. [CrossRef]

11. Al-Batran, S.E.; Hofheinz, R.D.; Pauligk, C.; Kopp, H.G.; Haag, G.M.; Luley, K.B.; Meiler, J.; Homann, N.; Lorenzen, S.; Schmalenberg, H.; et al. Histopathological regression after neoadjuvant docetaxel, oxaliplatin, fluorouracil, and leucovorin versus epirubicin, cisplatin, and fluorouracil or capecitabine in patients with resectable gastric or gastro-oesophageal junction adenocarcinoma (FLOT4-AIO): Results from the phase 2 part of a multicentre, open-label, randomised phase 2/3 trial. Lancet Oncol. 2016, 17, 1697-1708.

12. Vanhoefer, U.; Rougier, P.; Wilke, H.; Ducreux, M.P.; Lacave, A.J.; Van Cutsem, E.; Planker, M.; Dos Santos, J.G.; Piedbois, P.; Paillot, B.; et al. Final Results of a Randomized Phase III Trial of Sequential High-Dose Methotrexate, Fluorouracil, and Doxorubicin Versus Etoposide, Leucovorin, and Fluorouracil Versus Infusional Fluorouracil and Cisplatin in Advanced Gastric Cancer: A Trial of the European Organization for Research and Treatment of Cancer Gastrointestinal Tract Cancer Cooperative Group. J. Clin. Oncol. 2000, 18, 2648-2657. [PubMed]

13. Bang, Y.J.; Van Cutsem, E.; Feyereislova, A.; Chung, H.C.; Shen, L.; Sawaki, A.; Lordick, F.; Ohtsu, A.; Omuro, Y.; Satoh, T.; et al. Trastuzumab in combination with chemotherapy versus chemotherapy alone for treatment of HER2-positive advanced gastric or gastro-oesophageal junction cancer (ToGA): A phase 3, open-label, randomised controlled trial. Lancet 2010, 376, 687-697. [CrossRef]

14. Fuchs, C.S.; Tomasek, J.; Yong, C.J.; Dumitru, F.; Passalacqua, R.; Goswami, C.; Safran, H.; Dos Santos, L.V.; Aprile, G.; Ferry, D.R.; et al. Ramucirumab monotherapy for previously treated advanced gastric or gastro-oesophageal junction adenocarcinoma (REGARD): An international, randomised, multicentre, placebo-controlled, phase 3 trial. Lancet 2014, 383, 31-39. [CrossRef]

15. Kim, S.T.; Cristescu, R.; Bass, A.J.; Kim, K.M.; Odegaard, J.I.; Kim, K.; Liu, X.Q.; Sher, X.; Jung, H.; Lee, M.; et al. Comprehensive molecular characterization of clinical responses to PD-1 inhibition in metastatic gastric cancer. Nat. Med. 2018, 24, 1449-1458. [CrossRef]

16. Thrift, A.P.; El-Serag, H.B. Burden of Gastric Cancer. Clin. Gastroenterol. Hepatol. 2020, 18, 534-542. [CrossRef]

17. Gillet, J.-P.; Varma, S.; Gottesman, M.M. the Clinical relevance of Cancer Cell Lines. J. Natl. Cancer Inst. 2013, 105, 452-458. [CrossRef]

18. Sensi, F.; D'Angelo, E.; D'Aronco, S.; Molinaro, R.; Agostini, M. Preclinical three-dimensional colorectal cancer model: The next generation of in vitro drug efficacy evaluation. J. Cell. Physiol. 2018, 234, 181-191. [CrossRef]

19. Anton, D.; Burckel, H.; Josset, E.; Noel, G. Three-dimensional cell culture: A breakthrough in vivo. Int. J. Mol. Sci. 2015, 16, 5517-5527. [CrossRef]

20. Fayad, W.; Brnjic, S.; Berglind, D.; Blixt, S.; Shoshan, M.C.; Berndtsson, M.; Olofsson, M.H.; Linder, S. Restriction of cisplatin induction of acute apoptosis to a subpopulation of cells in a three-dimensional carcinoma culture model. Int. J. Cancer 2009, 125, 2450-2455. [CrossRef]

21. D’angelo, E.; Natarajan, D.; Sensi, F.; Ajayi, O.; Fassan, M.; Mammano, E.; Pilati, P.; Pavan, P.; Bresolin, S.; Preziosi, M.; et al. Patient-derived scaffolds of colorectal cancer metastases as an organotypic 3D model of the liver metastatic microenvironment. Cancers 2020, 12, 364. [CrossRef] [PubMed]

22. Katt, M.E.; Placone, A.L.; Wong, A.D.; Xu, Z.S.; Searson, P.C. In vitro tumor models: Advantages, disadvantages, variables, and selecting the right platform. Front. Bioeng. Biotechnol. 2016, 4, 12. [CrossRef] [PubMed] 
23. Sutherland, R.M.; Sordat, B.; Bamat, J.; Gabbert, H.; Bourrat, B.; Mueller-Klieser, W. Oxygenation and Differentiation in Multicellular Spheroids of Human Colon Carcinoma. Cancer Res. 1986, 46, 5320-5329. [PubMed]

24. Drost, J.; Clevers, H. Organoids in cancer research. Nat. Rev. Cancer 2018, 18, 407-418. [CrossRef] [PubMed]

25. Zanoni, M.; Cortesi, M.; Zamagni, A.; Arienti, C.; Pignatta, S.; Tesei, A. Modeling neoplastic disease with spheroids and organoids. J. Hematol. Oncol. 2020, 13, 1-15. [CrossRef] [PubMed]

26. Magalhães, L.; Quintana, L.G.; Lopes, D.C.F.; Vidal, A.F.; Pereira, A.L.; D’Araujo Pinto, L.C.; De Jesus Viana Pinheiro, J.; Khayat, A.S.; Goulart, L.R.; Burbano, R.; et al. APC gene is modulated by hsa-miR-135b-5p in both diffuse and intestinal gastric cancer subtypes. BMC Cancer 2018, 18, 1055. [CrossRef] [PubMed]

27. Sha, H.; Zou, Z.; Xin, K.; Bian, X.; Cai, X.; Lu, W.; Chen, J.; Chen, G.; Huang, L.; Blair, A.M.; et al. Tumor-penetrating peptide fused EGFR single-domain antibody enhances cancer drug penetration into 3D multicellular spheroids and facilitates effective gastric cancer therapy. J. Control. Release 2014, 200, 188-200. [CrossRef]

28. Bekaii-Saab, T.; El-Rayes, B. Identifying and targeting cancer stem cells in the treatment of gastric cancer. Cancer 2017, 123, 1303-1312. [CrossRef]

29. Sethi, N.S.; Kikuchi, O.; Duronio, G.N.; Stachler, M.D.; McFarland, J.M.; Ferrer-Luna, R.; Zhang, Y.; Bao, C.; Bronson, R.; Patil, D.; et al. Early TP53 alterations engage environmental exposures to promote gastric premalignancy in an integrative mouse model. Nat. Genet. 2020, 52, 219-230. [CrossRef]

30. McCracken, K.W.; Catá, E.M.; Crawford, C.M.; Sinagoga, K.L.; Schumacher, M.; Rockich, B.E.; Tsai, Y.-H.; Mayhew, C.N.; Spence, J.R.; Zavros, Y.; et al. Modelling human development and disease in pluripotent stem-cell-derived gastric organoids. Nature 2014, 516, 400-404. [CrossRef]

31. Friedrich, J.; Seidel, C.; Ebner, R.; Kunz-Schughart, L.A. Spheroid-based drug screen: Considerations and practical approach. Nat. Protoc. 2009, 4, 309-324. [CrossRef]

32. Liao, C.P.; Adisetiyo, H.; Liang, M.; Roy-Burman, P. Cancer-associated fibroblasts enhance the gland-forming capability of prostate cancer stem cells. Cancer Res. 2010, 70, 7294-7303. [CrossRef] [PubMed]

33. Togo, S.; Polanska, U.; Horimoto, Y.; Orimo, A. Carcinoma-Associated Fibroblasts Are a Promising Therapeutic Target. Cancers 2013, 5, 149-169. [CrossRef] [PubMed]

34. Cho, S.Y.; Kang, W.; Han, J.Y.; Min, S.; Kang, J.; Lee, A.; Kwon, J.Y.; Lee, C.; Park, H. An integrative approach to precision cancer medicine using patient-derived xenografts. Mol. Cells 2016, 39, 77-86. [PubMed]

35. Jung, J.; Seol, H.S.; Chang, S. The generation and application of patient-derived xenograft model for cancer research. Cancer Res. Treat. 2018, 50, 1-10. [CrossRef]

36. Byrne, A.T.; Alférez, D.G.; Amant, F.; Annibali, D.; Arribas, J.; Biankin, A.V.; Bruna, A.; Budinská, E.; Caldas, C.; Chang, D.K.; et al. Interrogating open issues in cancer precision medicine with patient-derived xenografts. Nat. Rev. Cancer 2017, 17, 254-268. [CrossRef]

37. Lin, M.; Gao, M.; Cavnar, M.J.; Kim, J. Utilizing gastric cancer organoids to assess tumor biology and personalize medicine. World J. Gastrointest. Oncol. 2019, 11, 509-517. [CrossRef]

38. Aberle, M.R.; Burkhart, R.A.; Tiriac, H.; Olde Damink, S.W.M.; Dejong, C.H.C.; Tuveson, D.A.; van Dam, R.M. Patient-derived organoid models help define personalized management of gastrointestinal cancer. Br. J. Surg. 2018, 105, e48-e60. [CrossRef]

39. Lau, H.C.H.; Kranenburg, O.; Xiao, H.; Yu, J. Organoid models of gastrointestinal cancers in basic and translational research. Nat. Rev. Gastroenterol. Hepatol. 2020, 17, 203-222. [CrossRef]

40. Van De Wetering, M.; Francies, H.E.; Francis, J.M.; Bounova, G.; Iorio, F.; Pronk, A.; Van Houdt, W.; Van Gorp, J.; Taylor-Weiner, A.; Kester, L.; et al. Prospective derivation of a living organoid biobank of colorectal cancer patients. Cell 2015, 161, 933-945. [CrossRef]

41. Schlaermann, P.; Toelle, B.; Berger, H.; Schmidt, S.C.; Glanemann, M.; Ordemann, J.; Bartfeld, S.; Mollenkopf, H.J.; Meyer, T.F. A novel human gastric primary cell culture system for modelling Helicobacter pylori infection in vitro. Gut 2016, 65, 202-213. [CrossRef] [PubMed]

42. Breslin, S.; O'Driscoll, L. Three-dimensional cell culture: The missing link in drug discovery. Drug Discov. Today 2013, 18, 240-249. [CrossRef] [PubMed]

43. Cancer Tissue Engineering-New Perspectives in Understand Google Scholar. Available online: https://sch olar.google.com/scholar?hl=en\&as_sdt=0\%2C5\&q=Cancer+tissue+engineering-New+perspectives+in+un derstanding+the+biology+of+solid+tumours-A+critical+review\&btnG= (accessed on 11 September 2020). 
44. Fischbach, C.; Chen, R.; Matsumoto, T.; Schmelzle, T.; Brugge, J.S.; Polverini, P.J.; Mooney, D.J. Engineering tumors with 3D scaffolds. Nat. Methods 2007, 4, 855-860. [CrossRef]

45. De-Souza, A.S.C.; Costa-Casagrande, T.A. Animal models for colorectal cancer. ABCD. Arq. Bras. Cir. Dig. 2018, 31. [CrossRef] [PubMed]

46. Inch, W.; Credie, J.; Sutherland, R. Growth of nodular carcinomas in rodents compared with multi-cell spheroids in tissue culture. Subj. Strain Bibliogr. 1970, 34, 271-282.

47. Hickman, J.A.; Graeser, R.; de Hoogt, R.; Vidic, S.; Brito, C.; Gutekunst, M.; van der Kuip, H. Imi Predect consortium Three-dimensional models of cancer for pharmacology and cancer cell biology: Capturing tumor complexity in vitro/ex vivo. Biotechnol. J. 2014, 9, 1115-1128. [CrossRef] [PubMed]

48. Hirschhaeuser, F.; Menne, H.; Dittfeld, C.; West, J.; Mueller-Klieser, W.; Kunz-Schughart, L.A. Multicellular tumor spheroids: An underestimated tool is catching up again. J. Biotechnol. 2010, 148, 3-15. [CrossRef]

49. Mehta, G.; Hsiao, A.Y.; Ingram, M.; Luker, G.D.; Takayama, S. Opportunities and challenges for use of tumor spheroids as models to test drug delivery and efficacy. J. Control. Release 2012, 164, 192-204. [CrossRef]

50. Ghosh, S.; Spagnoli, G.C.; Martin, I.; Ploegert, S.; Demougin, P.; Heberer, M.; Reschner, A. Three-dimensional culture of melanoma cells profoundly affects gene expression profile: A high density oligonucleotide array study. J. Cell. Physiol. 2005, 204, 522-531. [CrossRef]

51. Krueger, S.; Kalinski, T.; Wolf, H.; Kellner, U.; Roessner, A. Interactions between human colon carcinoma cells, fibroblasts and monocytic cells in coculture Regulation of cathepsin B expression and invasiveness. Cancer Lett. 2005, 223, 313-322. [CrossRef]

52. Lamichhane, S.P.; Arya, N.; Kohler, E.; Xiang, S.; Christensen, J.; Shastri, V.P. Recapitulating epithelial tumor microenvironment in vitro using three dimensional tri-culture of human epithelial, endothelial, and mesenchymal cells. BMC Cancer 2016, 16, 1-12. [CrossRef] [PubMed]

53. Sebrell, T.A.; Hashimi, M.; Sidar, B.; Wilkinson, R.A.; Kirpotina, L.; Quinn, M.T.; Malkoç, Z.; Taylor, P.J.; Wilking, J.N.; Bimczok, D. A Novel Gastric Spheroid Co-culture Model Reveals Chemokine-Dependent Recruitment of Human Dendritic Cells to the Gastric Epithelium. Cell. Mol. Gastroenterol. Hepatol. 2019, 8 , 157-171.e3. [CrossRef]

54. Ravi, M.; Paramesh, V.; Kaviya, S.R.; Anuradha, E.; Paul Solomon, F.D. 3D cell culture systems: Advantages and applications. J. Cell. Physiol. 2015, 230, 16-26. [CrossRef] [PubMed]

55. Place, E.S.; George, J.H.; Williams, C.K.; Stevens, M.M. Synthetic polymer scaffolds for tissue engineering. Chem. Soc. Rev. 2009, 38, 1139-1151. [CrossRef] [PubMed]

56. Estrada, M.F.; Rebelo, S.P.; Davies, E.J.; Pinto, M.T.; Pereira, H.; Santo, V.E.; Smalley, M.J.; Barry, S.T.; Gualda, E.J.; Alves, P.M.; et al. Modelling the tumour microenvironment in long-term microencapsulated 3D co-cultures recapitulates phenotypic features of disease progression. Biomaterials 2016, 78, 50-61. [CrossRef] [PubMed]

57. Yuhas, J.M.; Li, A.P.; Martinez, A.O.; Ladman, A.J. A Simplified Method for Production and Growth of Multicellular Tumor Spheroids. Cancer Res. 1977, 37, 3639-3643.

58. Yamada, K.M.; Cukierman, E. Modeling Tissue Morphogenesis and Cancer in 3D. Cell 2007, 130, 601-610. [CrossRef]

59. Lin, R.-Z.; Chang, H.-Y. Recent advances in three-dimensional multicellular spheroid culture for biomedical research. Biotechnol. J. 2008, 3, 1172-1184. [CrossRef]

60. Jørgensen, A.; Young, J.; Nielsen, J.E.; Joensen, U.N.; Toft, B.G.; Rajpert-De Meyts, E.; Loveland, K.L. Hanging drop cultures of human testis and testis cancer samples: A model used to investigate activin treatment effects in a preserved niche. Br. J. Cancer 2014, 110, 2604-2614. [CrossRef]

61. Kurosawa, H. Methods for inducing embryoid body formation: In vitro differentiation system of embryonic stem cells. J. Biosci. Bioeng. 2007, 103, 389-398. [CrossRef]

62. Fennema, E.; Rivron, N.; Rouwkema, J.; van Blitterswijk, C.; De Boer, J. Spheroid culture as a tool for creating 3D complex tissues. Trends Biotechnol. 2013, 31, 108-115. [CrossRef] [PubMed]

63. Huang, Y.; Li, X.; Sha, H.; Zhang, L.; Bian, X.; Han, X.; Liu, B. STRAIL-iRGD is a promising therapeutic agent for gastric cancer treatment. Sci. Rep. 2017, 7, 1-13. [CrossRef] [PubMed]

64. Mayer, B.; Klement, G.; Kaneko, M.; Man, S.; Jothy, S.; Rak, J.; Kerbel, R.S. Multicellular Gastric Cancer Spheroids Recapitulate Growth Pattern and Differentiation Phenotype of Human Gastric Carcinomas. Gastroenterology 2001, 121, 839-852. [CrossRef] [PubMed] 
65. Xiao, Y.; Pan, J.; Geng, Q.; Wang, G. Lnc RNA MALAT 1 increases the stemness of gastric cancer cells via enhancing SOX 2 mRNA stability. FEBS Open Bio 2019, 9, 1212-1222. [CrossRef]

66. Song, H.; Shi, L.; Xu, Y.; Xu, T.; Fan, R.; Cao, M.; Xu, W.; Song, J. BRD4 promotes the stemness of gastric cancer cells via attenuating miR-216a-3p-mediated inhibition of Wnt/ $\beta$-catenin signaling. Eur. J. Pharmacol. 2019, 852, 189-197. [CrossRef]

67. Liu, J.; Ma, L.; Wang, Z.; Wang, L.; Liu, C.; Chen, R.; Zhang, J. MicroRNA Expression Profile of Gastric Cancer Stem Cells in the MKN-45 Cancer Cell Line. Acta Biochim. Biophys. Sin. 2014, 46, 92-99. [CrossRef]

68. Kelm, J.M.; Timmins, N.E.; Brown, C.J.; Fussenegger, M.; Nielsen, L.K. Method for generation of homogeneous multicellular tumor spheroids applicable to a wide variety of cell types. Biotechnol. Bioeng. 2003, 83, 173-180. [CrossRef]

69. Yang, Z.; Wang, Z.; Fan, Y.; Zheng, Q. Expression of CD133 in SW620 colorectal cancer cells is modulated by the microenvironment. Oncol. Lett. 2012, 4, 75-79. [CrossRef]

70. Al-Husaini, K.; Elkamel, E.; Han, X.; Chen, P. Therapeutic potential of a cell penetrating peptide (CPP, NP1) mediated siRNA delivery: Evidence in 3D spheroids of colon cancer cells. Can. J. Chem. Eng. 2020, 98, 1240-1254. [CrossRef]

71. McLean, M.H.; El-Omar, E.M. Genetics of gastric cancer. Nat. Rev. Gastroenterol. Hepatol. 2014, 11, 664-674. [CrossRef]

72. Baker, B.M.; Chen, C.S. Deconstructing the third dimension-how 3D culture microenvironments alter cellular cues. J. Cell Sci. 2012, 125, 3015-3024. [CrossRef] [PubMed]

73. Ishimoto, T.; Nagano, O.; Yae, T.; Tamada, M.; Motohara, T.; Oshima, H.; Oshima, M.; Ikeda, T.; Asaba, R.; Yagi, H.; et al. CD44 Variant Regulates Redox Status in Cancer Cells by Stabilizing the xCT Subunit of System xc- and Thereby Promotes Tumor Growth. Cancer Cell 2011, 19, 387-400. [CrossRef] [PubMed]

74. Oue, N.; Mukai, S.; Imai, T.; Pham, T.T.B.; Oshima, T.; Sentani, K.; Sakamoto, N.; Yoshida, K.; Yasui, W. Induction of KIFC1 expression in gastric cancer spheroids. Oncol. Rep. 2016, 36, 349-355. [CrossRef] [PubMed]

75. Oue, N.; Sentani, K.; Sakamoto, N.; Uraoka, N.; Yasui, W. Molecular carcinogenesis of gastric cancer: Lauren classification, mucin phenotype expression, and cancer stem cells. Int. J. Clin. Oncol. 2019, 24, 771-778. [CrossRef] [PubMed]

76. Imai, T.; Oue, N.; Nishioka, M.; Mukai, S.; Oshima, T.; Sakamoto, N.; Sentani, K.; Matsusaki, K.; Yoshida, K.; Yasui, W. Overexpression of KIF11 in Gastric Cancer with Intestinal Mucin Phenotype. Pathobiology 2017, 84, 16-24. [CrossRef]

77. Kobayashi, G.; Sentani, K.; Hattori, T.; Yamamoto, Y.; Imai, T.; Sakamoto, N.; Kuraoka, K.; Oue, N.; Sasaki, N.; Taniyama, K.; et al. Clinicopathological significance of claspin overexpression and its association with spheroid formation in gastric cancer. Hum. Pathol. 2019, 84, 8-17. [CrossRef]

78. Lee, J.W.; Sung, J.S.; Park, Y.S.; Chung, S.; Kim, Y.H. Isolation of spheroid-forming single cells from gastric cancer cell lines: Enrichment of cancer stem-like cells. Biotechniques 2018, 65, 197-203. [CrossRef]

79. Lee, J.W.; Sung, J.S.; Park, Y.S.; Chung, S.; Kim, Y.H. Identification of different gene expressions between diffuse- and intestinal-type spheroid-forming gastric cancer cells. Gastric Cancer 2019, 22, 967-979. [CrossRef]

80. Birgersdotter, A.; Sandberg, R.; Ernberg, I. Gene expression perturbation in vitro A growing case for three-dimensional (3D) culture systems. Semin. Cancer Biol. 2005, 15, 405-412. [CrossRef]

81. Branco da Cunha, C.; Klumpers, D.D.; Koshy, S.T.; Weaver, J.C.; Chaudhuri, O.; Seruca, R.; Carneiro, F.; Granja, P.L.; Mooney, D.J. CD44 alternative splicing in gastric cancer cells is regulated by culture dimensionality and matrix stiffness. Biomaterials 2016, 98, 152-162. [CrossRef]

82. Da Cunha, C.B.; Oliveira, C.; Wen, X.; Gomes, B.; Sousa, S.; Suriano, G.; Grellier, M.; Huntsman, D.G.; Carneiro, F.; Granja, P.L.; et al. De novo expression of CD44 variants in sporadic and hereditary gastric cancer. Lab. Investig. 2010, 90, 1604-1614. [CrossRef] [PubMed]

83. Farnie, G.; Clarke, R.B. Mammary stem cells and breast cancer Role of notch signalling. Stem Cell Rev. 2007, 3, 169-175. [CrossRef] [PubMed]

84. Dubrovska, A.; Kim, S.; Salamone, R.J.; Walker, J.R.; Maira, S.M.; García-Echeverría, C.; Schultz, P.G.; Reddy, V.A. The role of PTEN/Akt/PI3K signaling in the maintenance and viability of prostate cancer stem-like cell populations. Proc. Natl. Acad. Sci. USA 2009, 106, 268-273. [CrossRef] [PubMed]

85. Wu, C.; Alman, B.A. Side population cells in human cancers. Cancer Lett. 2008, 268, 1-9. [CrossRef] [PubMed] 
86. Clarke, M.F.; Dick, J.E.; Dirks, P.B.; Eaves, C.J.; Jamieson, C.H.M.; Jones, D.L.; Visvader, J.; Weissman, I.L.; Wahl, G.M. Cancer stem cells Perspectives on current status and future directions: AACR workshop on cancer stem cells. Cancer Res. 2006, 66, 9339-9344. [CrossRef]

87. Zhang, X.; Hua, R.; Wang, X.; Huang, M.; Gan, L.; Wu, Z.; Zhang, J.; Wang, H.; Cheng, Y.; Li, J.; et al. Identification of stem-like cells and clinical significance of candidate stem cell markers in gastric cancer. Oncotarget 2016, 7, 9815-9831. [CrossRef] [PubMed]

88. Rocco, A.; Liguori, E.; Pirozzi, G.; Tirino, V.; Compare, D.; Franco, R.; Tatangelo, F.; Palaia, R.; D'Armiento, F.P.; Pollastrone, G.; et al. CD133 and CD44 Cell surface markers do not identify cancer stem cells in primary human gastric tumors. J. Cell. Physiol. 2012, 227, 2686-2693. [CrossRef]

89. Takaishi, S.; Okumura, T.; Tu, S.; Wang, S.S.W.; Shibata, W.; Vigneshwaran, R.; Gordon, S.A.K.; Shimada, Y.; Wang, T.C. Identification of Gastric Cancer Stem Cells Using the Cell Surface Marker CD44. Stem Cells 2009, 27, 1006-1020. [CrossRef]

90. Han, M.E.; Jeon, T.Y.; Hwang, S.H.; Lee, Y.S.; Kim, H.J.; Shim, H.E.; Yoon, S.; Baek, S.Y.; Kim, B.S.; Kang, C.D.; et al. Cancer spheres from gastric cancer patients provide an ideal model system for cancer stem cell research. Cell. Mol. Life Sci. 2011, 68, 3589-3605. [CrossRef]

91. Liu, J.; Ma, L.; Xu, J.; Liu, C.; Zhang, J.; Liu, J.; Chen, R.; Zhou, Y. Spheroid body-forming cells in the human gastric cancer cell line MKN-45 possess cancer stem cell properties. Int. J. Oncol. 2013, 42, 453-459. [CrossRef]

92. Liu, J.; Zhou, Y.; Ma, L.; Xu, J.; Liu, C.; Zhang, J.; Liu, J.; Chen, R.; Qian, H. Co-expression of CD44 and ABCG2 in spheroid body-forming cells of gastric cancer cell line MKN45. Hepatogastroenterology 2013, 60, 975-980. [PubMed]

93. Jiang, J.; Zhang, Y.; Chuai, S.; Wang, Z.; Zheng, D.; Xu, F.; Zhang, Y.; Li, C.; Liang, Y.; Chen, Z. Trastuzumab (herceptin) targets gastric cancer stem cells characterized by CD90 phenotype. Oncogene 2012, 31, 671-682. [CrossRef] [PubMed]

94. Tian, T.; Zhang, Y.; Wang, S.; Zhou, J.; Xu, S. Sox2 enhances the tumorigenicity and chemoresistance of cancer stem-like cells derived from gastric cancer. J. Biomed. Res. 2012, 26, 336-345. [CrossRef] [PubMed]

95. Song, Z.; Yue, W.; Wei, B.; Wang, N.; Li, T.; Guan, L.; Shi, S.; Zeng, Q.; Pei, X.; Chen, L. Sonic hedgehog pathway is essential for maintenance of cancer stem-like cells in human gastric cancer. PLoS ONE 2011, 6, e17687. [CrossRef] [PubMed]

96. Ohkuma, M.; Haraguchi, N.; Ishii, H.; Mimori, K.; Tanaka, F.; Kim, H.M.; Shimomura, M.; Hirose, H.; Yanaga, K.; Mori, M. Absence of CD71 transferrin receptor characterizes human gastric adenosquamous carcinoma stem cells. Ann. Surg. Oncol. 2012, 19, 1357-1364. [CrossRef]

97. Yoon, C.; Cho, S.J.; Aksoy, B.A.; Park, D.J.; Schultz, N.; Ryeom, S.W.; Yoon, S.S. Chemotherapy resistance in diffuse-type gastric adenocarcinoma is mediated by RhoA activation in cancer stem-like cells. Clin. Cancer Res. 2016, 22, 971-983. [CrossRef]

98. Atashzar, M.R.; Baharlou, R.; Karami, J.; Abdollahi, H.; Rezaei, R.; Pourramezan, F.; Zoljalali Moghaddam, S.H. Cancer stem cells: A review from origin to therapeutic implications. J. Cell. Physiol. 2020, 235, 790-803. [CrossRef]

99. Costa, E.C.; Moreira, A.F.; de Melo-Diogo, D.; Gaspar, V.M.; Carvalho, M.P.; Correia, I.J. 3D tumor spheroids: An overview on the tools and techniques used for their analysis. Biotechnol. Adv. 2016, 34, 1427-1441. [CrossRef]

100. Ocana, A.; Pandiella, A.; Siu, L.L.; Tannock, I.F. Preclinical development of molecular-targeted agents for cancer. Nat. Rev. Clin. Oncol. 2011, 8, 200-209. [CrossRef]

101. Longati, P.; Jia, X.; Eimer, J.; Wagman, A.; Witt, M.R.; Rehnmark, S.; Verbeke, C.; Toftgård, R.; Löhr, M.; Heuchel, R.L. 3D pancreatic carcinoma spheroids induce a matrix-rich, chemoresistant phenotype offering a better model for drug testing. BMC Cancer 2013, 13, 1-13. [CrossRef]

102. Courtois, S.; Durán, R.V.; Giraud, J.; Sifré, E.; Izotte, J.; Mégraud, F.; Lehours, P.; Varon, C.; Bessède, E. Metformin targets gastric cancer stem cells. Eur. J. Cancer 2017, 84, 193-201. [CrossRef] [PubMed]

103. Akrami, H.; Aminzadeh, S.; Fallahi, H. Inhibitory effect of ibuprofen on tumor survival and angiogenesis in gastric cancer cell. Tumor Biol. 2015, 36, 3237-3243. [CrossRef] [PubMed]

104. Akrami, H.; Moradi, B.; Borzabadi Farahani, D.; Mehdizadeh, K. Ibuprofen reduces cell proliferation through inhibiting Wnt/ $\beta$ catenin signaling pathway in gastric cancer stem cells. Cell Biol. Int. 2018, 42, 949-958. [CrossRef] 
105. Nishikawa, S.; Konno, M.; Hamabe, A.; Hasegawa, S.; Kano, Y.; Ohta, K.; Fukusumi, T.; Sakai, D.; Kudo, T.; Haraguchi, N.; et al. Aldehyde dehydrogenasehigh gastric cancer stem cells are resistant to chemotherapy. Int. J. Oncol. 2013, 42, 1437-1442. [CrossRef] [PubMed]

106. Koh, J.S.; Joo, M.K.; Park, J.J.; Yoo, H.S.; Choi, B.I.; Lee, B.J.; Chun, H.J.; Lee, S.W. Inhibition of STAT3 in gastric cancer: Role of pantoprazole as SHP-1 inducer. Cell Biosci. 2018, 8, 50. [CrossRef]

107. Minchinton, A.I.; Tannock, I.F. Drug penetration in solid tumours. Nat. Rev. Cancer 2006, 6, 583-592. [CrossRef] [PubMed]

108. Sha, H.; Li, R.; Bian, X.; Liu, Q.; Xie, C.; Xin, X.; Kong, W.; Qian, X.; Jiang, X.; Hu, W.; et al. A tumor-penetrating recombinant protein anti-EGFR-iRGD enhance efficacy of paclitaxel in 3D multicellular spheroids and gastric cancer in vivo. Eur. J. Pharm. Sci. 2015, 77, 60-72. [CrossRef] [PubMed]

109. Liu, R.; Ma, X.; Wang, H.; Xi, Y.; Qian, M.; Yang, W.; Luo, D.; Fan, L.; Xia, X.; Zhou, J.; et al. The novel fusion protein sTRAIL-TMTP1 exhibits a targeted inhibition of primary tumors and metastases. J. Mol. Med. 2014, 92, 165-175. [CrossRef]

110. Sherman, H.; Gitschier, H.J.; Rossi, A.E. A novel three-dimensional immune oncology model for high-throughput testing of tumoricidal activity. Front. Immunol. 2018, 9, 857. [CrossRef]

111. Zhou, S.; Zhu, M.; Meng, F.; Shao, J.; Xu, Q.; Wei, J.; Liu, B. Evaluation of PD-1 blockade using a multicellular tumor spheroid model. Am. J. Transl. Res. 2019, 11, 7471-7478.

112. Salmaninejad, A.; Valilou, S.F.; Shabgah, A.G.; Aslani, S.; Alimardani, M.; Pasdar, A.; Sahebkar, A. PD-1/PD-L1 pathway: Basic biology and role in cancer immunotherapy. J. Cell. Physiol. 2019, 234, 16824-16837. [CrossRef] [PubMed]

113. Langhans, S.A. Three-dimensional in vitro cell culture models in drug discovery and drug repositioning. Front. Pharmacol. 2018, 9, 6. [CrossRef] [PubMed]

114. Pattabiraman, D.R.; Weinberg, R.A. Tackling the cancer stem cells-what challenges do they pose? Nat. Rev. Drug Discov. 2014, 13, 497-512. [CrossRef] [PubMed]

115. Das, V.; Fürst, T.; Gurská, S.; Džubák, P.; Hajdúch, M. Reproducibility of uniform spheroid formation in 384-well plates: The effect of medium evaporation. J. Biomol. Screen. 2016, 21, 923-930. [CrossRef] [PubMed]

116. Eiraku, M.; Sasai, Y. Self-formation of layered neural structures in three-dimensional culture of ES cells. Curr. Opin. Neurobiol. 2012, 22, 768-777. [CrossRef] [PubMed]

117. Werner, K.; Weitz, J.; Stange, D.E. Organoids as Model Systems for Gastrointestinal Diseases: Tissue Engineering Meets Genetic Engineering. Curr. Pathobiol. Rep. 2016, 4, 1-9. [CrossRef]

118. Neal, J.T.; Li, X.; Zhu, J.; Giangarra, V.; Grzeskowiak, C.L.; Ju, J.; Liu, I.H.; Chiou, S.H.; Salahudeen, A.A.; Smith, A.R.; et al. Organoid Modeling of the Tumor Immune Microenvironment. Cell 2018, 175, 1972-1988.e16. [CrossRef]

119. Sato, T.; Stange, D.E.; Ferrante, M.; Vries, R.G.J.; Van Es, J.H.; Van Den Brink, S.; Van Houdt, W.J.; Pronk, A.; Van Gorp, J.; Siersema, P.D.; et al. Long-term expansion of epithelial organoids from human colon, adenoma, adenocarcinoma, and Barrett's epithelium. Gastroenterology 2011, 141, 1762-1772. [CrossRef]

120. Barker, N.; Van Es, J.H.; Kuipers, J.; Kujala, P.; Van Den Born, M.; Cozijnsen, M.; Haegebarth, A.; Korving, J.; Begthel, H.; Peters, P.J.; et al. Identification of stem cells in small intestine and colon by marker gene Lgr5. Nature 2007, 449, 1003-1007. [CrossRef]

121. Sato, T.; Vries, R.G.; Snippert, H.J.; Van De Wetering, M.; Barker, N.; Stange, D.E.; Van Es, J.H.; Abo, A.; Kujala, P.; Peters, P.J.; et al. Single Lgr5 stem cells build crypt-villus structures in vitro without a mesenchymal niche. Nature 2009, 459, 262-265. [CrossRef]

122. Boj, S.F.; Hwang, C.I.; Baker, L.A.; Chio, I.I.C.; Engle, D.D.; Corbo, V.; Jager, M.; Ponz-Sarvise, M.; Tiriac, H.; Spector, M.S.; et al. Organoid models of human and mouse ductal pancreatic cancer. Cell 2015, 160, 324-338. [CrossRef]

123. Huch, M.; Gehart, H.; Van Boxtel, R.; Hamer, K.; Blokzijl, F.; Verstegen, M.M.A.; Ellis, E.; Van Wenum, M.; Fuchs, S.A.; De Ligt, J.; et al. Long-term culture of genome-stable bipotent stem cells from adult human liver. Cell 2015, 160, 299-312. [CrossRef]

124. DeWard, A.D.; Cramer, J.; Lagasse, E. Cellular heterogeneity in the mouse esophagus implicates the presence of a nonquiescent epithelial stem cell population. Cell Rep. 2014, 9, 701-711. [CrossRef]

125. Chua, C.W.; Shibata, M.; Lei, M.; Toivanen, R.; Barlow, L.J.; Bergren, S.K.; Badani, K.K.; McKiernan, J.M.; Benson, M.C.; Hibshoosh, H.; et al. Single luminal epithelial progenitors can generate prostate organoids in culture. Nat. Cell Biol. 2014, 16, 951-961. [CrossRef] 
126. Wong, A.P.; Bear, C.E.; Chin, S.; Pasceri, P.; Thompson, T.O.; Huan, L.J.; Ratjen, F.; Ellis, J.; Rossant, J. Directed differentiation of human pluripotent stem cells into mature airway epithelia expressing functional CFTR protein. Nat. Biotechnol. 2012, 30, 876-882. [CrossRef]

127. Sachs, N.; de Ligt, J.; Kopper, O.; Gogola, E.; Bounova, G.; Weeber, F.; Balgobind, A.V.; Wind, K.; Gracanin, A.; Begthel, H.; et al. A Living Biobank of Breast Cancer Organoids Captures Disease Heterogeneity. Cell 2018, 172, 373-386.e10. [CrossRef]

128. Clevers, H. Modeling Development and Disease with Organoids. Cell 2016, 165, 1586-1597. [CrossRef] [PubMed]

129. Barker, N.; Huch, M.; Kujala, P.; van de Wetering, M.; Snippert, H.J.; van Es, J.H.; Sato, T.; Stange, D.E.; Begthel, H.; van den Born, M.; et al. Lgr5+ve Stem Cells Drive Self-Renewal in the Stomach and Build Long-Lived Gastric Units In Vitro. Cell Stem Cell 2010, 6, 25-36. [CrossRef] [PubMed]

130. Stange, D.E.; Koo, B.K.; Huch, M.; Sibbel, G.; Basak, O.; Lyubimova, A.; Kujala, P.; Bartfeld, S.; Koster, J.; Geahlen, J.H.; et al. XDifferentiated Troy+ chief cells act as reserve stem cells to generate all lineages of the stomach epithelium. Cell 2013, 155, 357. [CrossRef] [PubMed]

131. Seidlitz, T.; Merker, S.R.; Rothe, A.; Zakrzewski, F.; Von Neubeck, C.; Grützmann, K.; Sommer, U.; Schweitzer, C.; Schölch, S.; Uhlemann, H.; et al. Human gastric cancer modelling using organoids. Gut 2019, 68, 207-217. [CrossRef]

132. Gao, D.; Vela, I.; Sboner, A.; Iaquinta, P.J.; Karthaus, W.R.; Gopalan, A.; Dowling, C.; Wanjala, J.N.; Undvall, E.A.; Arora, V.K.; et al. Organoid cultures derived from patients with advanced prostate cancer. Cell 2014, 159, 176-187. [CrossRef] [PubMed]

133. Gao, M.; Lin, M.; Rao, M.; Thompson, H.; Hirai, K.; Choi, M.; Georgakis, G.V.; Sasson, A.R.; Bucobo, J.C.; Tzimas, D.; et al. Development of Patient-Derived Gastric Cancer Organoids from Endoscopic Biopsies and Surgical Tissues. Ann. Surg. Oncol. 2018, 25, 2767-2775. [CrossRef] [PubMed]

134. Hughes, C.S.; Postovit, L.M.; Lajoie, G.A. Matrigel: A complex protein mixture required for optimal growth of cell culture. Proteomics 2010, 10, 1886-1890. [CrossRef] [PubMed]

135. Bartfeld, S.; Bayram, T.; Van De Wetering, M.; Huch, M.; Begthel, H.; Kujala, P.; Vries, R.; Peters, P.J.; Clevers, H. In vitro expansion of human gastric epithelial stem cells and their responses to bacterial infection. Gastroenterology 2015, 148, 126-136.e6. [CrossRef]

136. Yan, H.H.N.; Siu, H.C.; Law, S.; Ho, S.L.; Yue, S.S.K.; Tsui, W.Y.; Chan, D.; Chan, A.S.; Ma, S.; Lam, K.O.; et al. A Comprehensive Human Gastric Cancer Organoid Biobank Captures Tumor Subtype Heterogeneity and Enables Therapeutic Screening. Cell Stem. Cell 2018, 23, 882-897.e11. [CrossRef]

137. Nanki, K.; Toshimitsu, K.; Takano, A.; Fujii, M.; Shimokawa, M.; Ohta, Y.; Matano, M.; Seino, T.; Nishikori, S.; Ishikawa, K.; et al. Divergent Routes toward Wnt and R-spondin Niche Independency during Human Gastric Carcinogenesis. Cell 2018, 174, 856-869.e17. [CrossRef]

138. Vlachogiannis, G.; Hedayat, S.; Vatsiou, A.; Jamin, Y.; Fernández-Mateos, J.; Khan, K.; Lampis, A.; Eason, K.; Huntingford, I.; Burke, R.; et al. Patient-derived organoids model treatment response of metastatic gastrointestinal cancers. Science 2018, 359, 920-926. [CrossRef]

139. Hooi, J.K.Y.; Lai, W.Y.; Ng, W.K.; Suen, M.M.Y.; Underwood, F.E.; Tanyingoh, D.; Malfertheiner, P.; Graham, D.Y.; Wong, V.W.S.; Wu, J.C.Y.; et al. Global Prevalence of Helicobacter pylori Infection: Systematic Review and Meta-Analysis. Gastroenterology 2017, 153, 420-429. [CrossRef]

140. Salama, N.R.; Hartung, M.L.; Müller, A. Life in the human stomach: Persistence strategies of the bacterial pathogen Helicobacter pylori. Nat. Rev. Microbiol. 2013, 11, 385-399. [CrossRef]

141. Camilo, V.; Sugiyama, T.; Touati, E. Pathogenesis of Helicobacter pylori infection. Helicobacter 2017, 22 , e12405. [CrossRef]

142. Odenbreit, S.; Püls, J.; Sedlmaier, B.; Gerland, E.; Fischer, W.; Haas, R. Translocation of Helicobacter pylori CagA into gastric epithelial cells by type IV secretion. Science 2000, 287, 1497-1500. [CrossRef] [PubMed]

143. Xiao, C.; Ogle, S.A.; Schumacher, M.A.; Orr-Asman, M.A.; Miller, M.L.; Lertkowit, N.; Varro, A.; Hollande, F.; Zavros, Y. Loss of Parietal Cell Expression of Sonic Hedgehog Induces Hypergastrinemia and Hyperproliferation of Surface Mucous Cells. Gastroenterology 2010, 138, 550-561. [CrossRef] [PubMed]

144. Schumacher, M.A.; Donnelly, J.M.; Engevik, A.C.; Xiao, C.; Yang, L.; Kenny, S.; Varro, A.; Hollande, F.; Samuelson, L.C.; Zavros, Y. Gastric sonic hedgehog acts as a macrophage chemoattractant during the immune response to Helicobacter pylori. Gastroenterology 2012, 142, 1150-1159.e6. [CrossRef] 
145. Schumacher, M.A.; Feng, R.; Aihara, E.; Engevik, A.C.; Montrose, M.H.; Ottemann, K.M.; Zavros, Y. Helicobacter pylori-induced sonic hedgehog expression is regulated by NFKB pathway activation: The use of a novel in vitro model to study epithelial response to infection. Helicobacter 2015, 20, 19-28. [CrossRef] [PubMed]

146. Wroblewski, L.E.; Piazuelo, M.B.; Chaturvedi, R.; Schumacher, M.; Aihara, E.; Feng, R.; Noto, J.M.; Delgado, A.; Israel, D.A.; Zavros, Y.; et al. Helicobacter pylori targets cancer-associated apical-junctional constituents in gastroids and gastric epithelial cells. Gut 2015, 64, 720-730. [CrossRef] [PubMed]

147. Bertaux-Skeirik, N.; Feng, R.; Schumacher, M.A.; Li, J.; Mahe, M.M.; Engevik, A.C.; Javier, J.E.; Peek, R.M., Jr.; Ottemann, K.; Orian-Rousseau, V.; et al. CD44 Plays a Functional Role in Helicobacter pylori-induced Epithelial Cell Proliferation. PLoS Pathog. 2015, 11, e1004663. [CrossRef]

148. Sigal, M.; Rothenberg, M.E.; Logan, C.Y.; Lee, J.Y.; Honaker, R.W.; Cooper, R.L.; Passarelli, B.; Camorlinga, M.; Bouley, D.M.; Alvarez, G.; et al. Helicobacter pylori activates and expands Lgr5+ stem cells through direct colonization of the gastric glands. Gastroenterology 2015, 148, 1392-1404.e21. [CrossRef]

149. Holokai, L.; Chakrabarti, J.; Broda, T.; Chang, J.; Hawkins, J.A.; Sundaram, N.; Wroblewski, L.E.; Peek, R.M.; Wang, J.; Helmrath, M.; et al. Increased Programmed Death-Ligand 1 is an Early Epithelial Cell Response to Helicobacter pylori Infection. PLoS Pathog. 2019, 15, e1007468. [CrossRef]

150. Hayakawa, Y.; Fox, J.G.; Gonda, T.; Worthley, D.L.; Muthupalani, S.; Wang, T.C. Mouse models of gastric cancer. Cancers 2013, 5, 92-130. [CrossRef]

151. Matano, M.; Date, S.; Shimokawa, M.; Takano, A.; Fujii, M.; Ohta, Y.; Watanabe, T.; Kanai, T.; Sato, T. Modeling colorectal cancer using CRISPR-Cas9-mediated engineering of human intestinal organoids. Nat. Med. 2015, 21, 256-262. [CrossRef]

152. Chen, J.; Lau, B.T.; Andor, N.; Grimes, S.M.; Handy, C.; Wood-Bouwens, C.; Ji, H.P. Single-cell transcriptome analysis identifies distinct cell types and niche signaling in a primary gastric organoid model. Sci. Rep. 2019, 9, 1-12. [CrossRef] [PubMed]

153. Wang, X.; Liang, Q.; Zhang, L.; Gou, H.; Li, Z.; Chen, H.; Dong, Y.; Ji, J.; Yu, J. C8orf76 promotes gastric tumorigenicity and metastasis by directly inducing lncRNA DUSP5P1 and associates with patient outcomes. Clin. Cancer Res. 2019, 25, 3128-3140. [CrossRef]

154. Roerink, S.F.; Sasaki, N.; Lee-Six, H.; Young, M.D.; Alexandrov, L.B.; Behjati, S.; Mitchell, T.J.; Grossmann, S.; Lightfoot, H.; Egan, D.A.; et al. Intra-tumour diversification in colorectal cancer at the single-cell level. Nature 2018, 556, 437-462. [CrossRef] [PubMed]

155. Xue, X.; Shah, Y.M. In vitro organoid culture of primary mouse colon tumors. J. Vis. Exp. 2013, 17, e50210. [CrossRef] [PubMed]

156. Steele, N.G.; Chakrabarti, J.; Wang, J.; Biesiada, J.; Holokai, L.; Chang, J.; Nowacki, L.M.; Hawkins, J.; Mahe, M.; Sundaram, N.; et al. An Organoid-Based Preclinical Model of Human Gastric Cancer. CMGH 2019, 7, 161-184. [CrossRef]

157. Li, J.; Xu, H.; Zhang, L.; Song, L.; Feng, D.; Peng, X.; Wu, M.; Zou, Y.; Wang, B.; Zhan, L.; et al. Malignant ascites-derived organoid (MADO) cultures for gastric cancer in vitro modelling and drug screening. J. Cancer Res. Clin. Oncol. 2019, 145, 2637-2647. [CrossRef]

158. Gambardella, V.; Tarazona, N.; Cejalvo, J.M.; Lombardi, P.; Huerta, M.; Roselló, S.; Fleitas, T.; Roda, D.; Cervantes, A. Personalized Medicine: Recent Progress in Cancer Therapy. Cancers 2020, 12, 1009. [CrossRef]

159. OPPOSITE: Outcome Prediction Of Systemic Treatment in Esophagogastric Carcinoma Full Text View ClinicalTrials.gov. Available online: https:/clinicaltrials.gov/ct2/show/NCT03429816 (accessed on 16 May 2020).

(C) 2020 by the authors. Licensee MDPI, Basel, Switzerland. This article is an open access article distributed under the terms and conditions of the Creative Commons Attribution (CC BY) license (http://creativecommons.org/licenses/by/4.0/). 